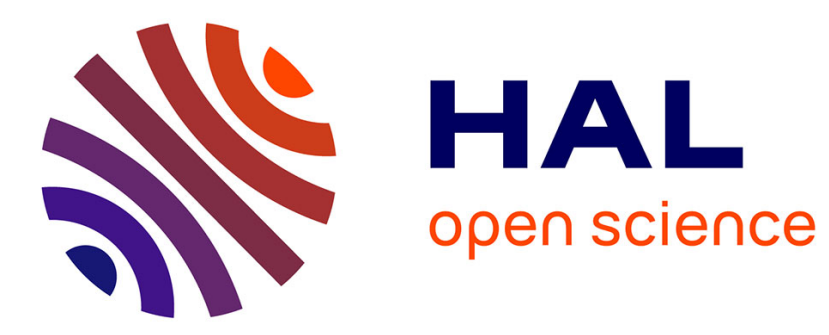

\title{
Malaria and Primary Education: A Cross-Country Analysis on Primary Repetition and Completion Rates
} Josselin Thuilliez

\section{To cite this version:}

Josselin Thuilliez. Malaria and Primary Education: A Cross-Country Analysis on Primary Repetition and Completion Rates. 2007. halshs-00144666

\section{HAL Id: halshs-00144666 \\ https://shs.hal.science/halshs-00144666}

Submitted on 4 May 2007

HAL is a multi-disciplinary open access archive for the deposit and dissemination of scientific research documents, whether they are published or not. The documents may come from teaching and research institutions in France or abroad, or from public or private research centers.
L'archive ouverte pluridisciplinaire HAL, est destinée au dépôt et à la diffusion de documents scientifiques de niveau recherche, publiés ou non, émanant des établissements d'enseignement et de recherche français ou étrangers, des laboratoires publics ou privés. 


\section{Documents de Travail du Centre d'Economie de la Sorbonne}

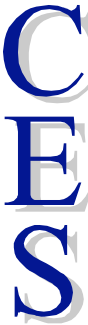

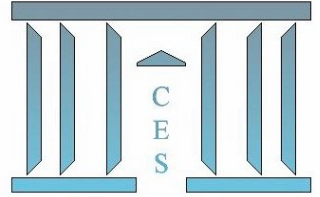

Malaria and Primary Education : A Cross-Country Analysis on Primary Repetition and Completion Rates

Josselin THUILLIEZ

2007.13 


\title{
Malaria and Primary Education \\ A Cross-Country Analysis on Primary Repetition and Completion Rates
}

\author{
Josselin THUILLIEZ \\ CES-TEAM, Université Paris1 PANTHEON-SORBONNE et CNRS \\ Josselin.Thuilliez@malix.univ-paris1.fr
}

\begin{abstract}
This paper explores the link between P. Falciparum malaria - most of malaria morbidity and mortality is due to the malignant Plasmodium Falciparum - and primary education in terms of school performances at the macroeconomic stage. Cross-country regression analysis shows that the relation between school results (measured by repetition and completion rates) and the P. Falciparum malaria index is strong. The results implies that the achievement of the education Millennium Development Goals will require more than just focusing on expenditure in primary education. It does not imply that resources in education are unnecessary but that increasing resources in education and improving education resources management alone are unlikely to be sufficient. This paper suggests that health conditions and especially diseases that alter cognitive capacities of children such as malaria should be taken into account much more seriously. This study also sees the need to place emphasis on research that will improve the quality of interventions to prevent malaria. Specific education expenditure to face Malaria should be examined in addition to health policies.
\end{abstract}

Key words: Malaria incidence - Human Capital - Development.

JEL: 015 - I10 - I20

Résumé : Ce travail explore la relation entre le paludisme à P.falciparum - le seul mortel et le plus répandu - et l'éducation primaire en termes de résultats scolaires au niveau macroéconomique. L'analyse en coupe transversale réalisée montre que le lien entre les performances des enfants dans le primaire (mesurées par les taux de redoublement et d'achèvement dans le primaire) et l'indice de paludisme à P.falciparum utilisé est fort.

Ces résultats laissent penser que l'accomplissement de l'objectif d'éducation universelle nécessite une approche plus large et non uniquement focalisée sur les dépenses d'éducation (publiques ou privés) mais aussi sur des dépenses de santé spécifiques. Cela ne veut pas dire que les efforts réalisés jusqu'ici sont inutiles. Cela semble vouloir dire que pour améliorer la qualité de l'éducation, il faut également prendre en compte l'état de santé des enfants et les maladies affectant particulièrement leurs capacités cognitives dont le paludisme. Les dépenses spécifiques d'éducation et de santé pour faire face au fléau du paludisme devraient faire l'objet de recherches plus approfondies.

Mots clés: Paludisme - Capital Humain - Développement.

JEL: O15 - I10 - I20 


\section{INTRODUCTION}

Malaria ranks among the foremost public health and development issues facing tropical countries. The numbers are staggering: an estimated $41 \%$ of the world population is living in areas where malaria is transmitted; there are 300 to 500 million clinical cases every year. The disease currently kills between 700000 and 2,7 million people per year, $75 \%$ of them are African children. Around $30 \%$ of external consultations and $20 \%$ to $40 \%$ of hospitalisations in Africa are due to Malaria. The Roll Back Malaria partnership proposes to halve malaria burden in countries participating to the initiative by the year 2010 .

Why are malarious countries poorer? Why do they grow less than non-malarious countries? A series of papers have explored the link between economic development and malaria ${ }^{1}$. Contrary to other tropical diseases and since the failure of eradication efforts in the 80 's, malaria has been described as an unavoidable effect of tropical location and natural forces (heavy rains, floods...) Therefore recent empirical studies have used malaria as an exogenous variable in the regressions of economic growth and income level on malaria endemicity. Nevertheless, the transmission channels are still little known.

Sachs \& Gallup (2001), using a malaria exposure index defined as the fraction of population at risk of contracting falciparum malaria in a country, show that poverty is not a leading cause of malaria, ceteris paribus. The ecological conditions that allow the reproduction and development of vectors determine the intensity and distribution of the disease. In a cross-country regression framework, the authors find that countries with intensive malaria are poorer and grew 1.3\% less per person per year. These results point to causation from malaria to poverty, not vice versa. On the contrary, in Acemoglu, Johnson \& Robinson (2002), malaria "is unlikely to be the reason why many countries in Africa and Asia are very poor today"2. Whatever the conclusions may be, the role of malaria as a "killer", a "weakener" and as an element in this "vicious circle, which makes the poor malarious and the malarious poor" (Watts, 1999) is well acknowledged now.

In another article, McCarthy et al. (2000), using estimates of malaria morbidity from the World Health Organization (WHO), suggest that economic development may influence malaria control. They confirm the dominant role of climate in determining malaria intensity and the negative correlation between malaria and growth but find that access to rural healthcare and income equality also influence malaria morbidity once controlling for climate. It raises the problem of endogeneity of malaria respect to growth and the robustness of the results in this field of research.

A natural way to study growth is to identify and quantify in detail all the possible transmission channels (Rodrik \& Rodriguez, 2000). As human capital formation and accumulation have been shown to be some key variables in the growth and development of countries, this paper explores the impact of malaria on human capital development in children. As basic education and health are ends in themselves, this paper may contribute to understand the suffering of individuals and communities in affected areas. We investigate this issue using a dataset from Samer Al-Samarrai (2006) to estimate in a cross-country regression framework the impact of an index of malaria endemicity for 1994 on repetition and completion rates in 1996. We control for other variables already used in the literature on the determinants of primary education quality. We add indicators of general health conditions, governance and climate in the model and check the robustness of our results with a series of tests. Our results suggest that high levels of malaria endemicity increase repetition rates and

\footnotetext{
${ }^{1}$ See for instance McDonald (1950), Barlow (1967), Newman (1968), Gomes (1993) and Audibert et al. (1999).

${ }^{2}$ It should be noted that the relationship between malaria and growth is not the primary focus of this study.
} 
decrease completion rates, ceteris paribus. These findings fill part of the gap between microeconomic assessments of the impact of malaria and macroeconomic ones identifying one of the macroeconomic channels of the impact of the disease on development.

The next section gives the conceptual framework of the study and a summary of previous literature on the link between malaria and school performances. Section 3 describes variables and methodology used in the study. Section 4 presents our cross-country regressions results. We finally discuss the results and conclude in section 5.

\section{BACKGROUND AND PREVIOUS LITTERATURE}

\section{The link between malaria and school performances: some medical and empirical evidences.}

Malaria is a parasitic disease transmitted by anopheles mosquitoes that results from biological developments of protozoal parasites. In this study, we only focus on the $P$. falciparum malaria, which is far more severe than the other types of malaria. The incidence and severity of $P$. Falciparum malaria depends on various entomological, environmental and human factors. Possible combinations between factors are numerous. Clinical presentation of malaria varies, among other factors such as personal behaviour or genetic characteristics, according the immune status. Populations exposed to frequent infections acquire partial labile protective malarial immunity. The level of immunity affects not only mortality, severity of malaria but also uncomplicated malarial attacks. Therefore and paradoxically, it is more difficult to assess the real burden of the pathology in highly endemic areas where people are more exposed to mosquitoes infected bites since parazitation is not directly and proportionally associated with apparent clinical symptoms. On the contrary, diagnosis is supposed to be easier in low endemic areas where symptoms are directly caused by infection in the absence of immunity. Acquired immunity of children does not play an efficient protective role until the age of 5-6 years, even in highly endemic areas. That is partly why malaria is a major threat to child survival. In 2000-2003, malaria accounted for $8 \%$ of the 10.6 million yearly deaths in children younger than age 5 years (WHO-CHERG). It was the third cause of under5-years mortality. 94\% of global child deaths attributable to the disease occur in Africa (Bryce et al., 2005). In holoendemic areas of Africa (where transmission is said to be stable), the disease represents 20 to $25 \%$ of all causes of $0-5$-child mortality, $25 \%$ of paediatrics hospitalisations, and lethality is around $15 \%$. Because of a depression of acquired immunity during pregnancy, malaria also causes acute disease during pregnancy with severe health consequences for both the mother and the child ${ }^{3}$.

A number of studies have emphasized the consequences of malaria on child behavioural and cognitive development, learning performances and school attendance. Nevertheless, the relationship is only beginning to be explored. We can summarize the direct links between malaria and school performances with the very simplified scheme given in Figure1. Other socioeconomic externalities may contribute to amplify this impact of malaria on school outcomes.

In 1917, the Texas State Health Department, the University of Texas Extension Department and the International Health Board made a first attempt to mead the effects of malaria upon physical and mental development (Kelley, 1917). One interesting conclusion is that the cure from malaria leads to immediate increase in physical and mental development but the article does not give any explanation on the causal relationship. Moreover, the method

\footnotetext{
${ }^{3}$ For an historical perspective of childhood malaria mortality in Africa see Snow et al. (2001). For a review of the economic effects of malaria in pregnancy see Worrall et al. (2007).
} 
and data used in this study remain very crude. McDonald (1945) also underlines the consequences of malaria on child education through absenteeism and chronic infections. Until the 80 's, research in this field has not progressed and the indirect as well as the direct consequences of the disease on child development have been neglected.

In a recent unpublished paper with an historical perspective, Bleakley (2006) considers the malaria-eradication campaigns in the United-States (1920), in Brazil, Colombia and Mexico (1950) to assess the impact of childhood exposure to malaria on labour productivity. Using a cohort-level dataset based on microeconomic data, the author finds that the cohorts born after eradication had higher literacy once adult than the preceding generation. The effect of childhood malaria exposure on adult is similar for the four countries considered.

Holding \& Snow (2001) made a review of the evidences of the impacts of P. Falciparum malaria on performance and learning through neurological impairment after cerebral malaria, brain insults during malaria, complications of clinical cases, malaria induced-anaemia, nutritional effects, fetal exposure to malaria, low birth weight and prematurity. For instance, on a total of 1854 Kenyan children with cerebral malaria, they found that 302 died $(16.3 \%)$ and 248 (16\% of survivors) were reported to have neurological sequels at discharge. These figures do not mean that the sequels will be accompanied by widespread impairment of cognitive functions or learning capacities but the association seems to exist. Our study will try to quantify this impact of malaria on school performance at a macroeconomic stage. Another review of evidences (M. Kihara et al., 2006) finds similar conclusions and gives more precisions about the cognitive impacts of malaria. Deficits in attention, memory, visuo-spatial skills, language and executive functions may occur after malaria infection. These deficits are not only caused by cerebral falciparum malaria, but also appear to occur in less severe infections. Finally, Holding \& Kitsao-Wekulo (2004) describe the priorities for future research in this field. The wide range of potential pathways to impaired development need to be investigated with different methods. Understanding the source of the variability in outcome (differences in socioeconomic status, presence of other infections, age, environment) could also help to identify malaria specific impact, children most at risk and intervention modalities.

In two case studies realised in Sri Lanka (Fernando et al, 2003), it was found that malaria infections and repeated malaria infections have an adverse impact on school performances (measured by test scores in mathematics and language after controlling for socio-economic variables such as the education level of adults, household's income, habitation types and nutritional status.) For instance, within 571 school children of 6-14 years, a child who experienced more than five attacks of malaria scored approximately $15 \%$ less than a child who experienced less than three attacks of malaria. The cognitive performance at school entry of 325 schoolchildren of 5-6 years in grade 1 in two endemic districts decreases as the number of malaria infections increases. These studies suggest that malaria in malaria-endemic areas can have an adverse impact on cognitive capacities not only at school entry but also during primary schooling.

Malaria can have non-cognitive consequences through school absenteeism, general health conditions, or other socio-economic conditions and behaviours associated with the disease. For instance, in a case study made in Kenya, Brooker et al. (2000) attribute 13-50\% of medically related school absences to malaria. Leighton \& Foster (1993) also provide evidence on the number of school days lost due to malaria in Kenya and Nigeria. In Kenya, primary school students were considered to miss $11 \%$ of the school year $(20$ school days missed per child per year). In Nigeria, school days missed varied between $2 \%$ to $6 \%$ of the school year ( 3 to 12 days per year per student). In the Muea area in Cameroun, Kimbi et al.(2005) evaluate that 53 out of $144(36.8 \%)$ malarious children lose a number of school days ranging from 0.5 to 14 days, with each child losing an average of 1.53 school days in a month. Social and economic costs of the disease can amplify absences: parents can retain children at home 
to take care of younger siblings who are sick or make other household or productive tasks. This may occur especially in agricultural economies where farming activities are a family affair and because of coping mechanisms (Chima et al. 2003). Nevertheless these conclusions remain speculative because we still know very little about the impact of malaria on school attendance. Absenteeism in developing countries can be due to many reasons unrelated to malaria.

Malaria is associated with a number of neglected tropical diseases like hookworm, schistosomiasis, onchocerciasis, filariasis, dengue fever, trypanosomiasis,... Brooker et al. (2006) suggest that the control of malaria and parasitic helminths in school children could be viewed as essential co-contributors to promoting health of schoolchildren. Malaria incidence can be increased by the coinfection with the other tropical diseases.

All these studies tend to describe a complex relationship between malaria infection, human capital formation and the great number of risk factors, which themselves may be associated with performance at school. Our purpose here is not to make an exhaustive literature review of the micro impacts of malaria on cognitive and learning capacities of children. We just underline that the few case studies that have explored the question conclude that the link is strong. Health microeconomic literature also recognizes that physical and mental health problems can impede children's human capital accumulation (see for instance Currie \& Stabile, 2006). Hence, it would be surprising not to encounter the impact of malaria at the macroeconomic stage, all the more that the disease creates other negative external effects that can amplify the phenomenon.

FIGURE 1: Direct Impacts of Malaria on School Performance (Source: Author).

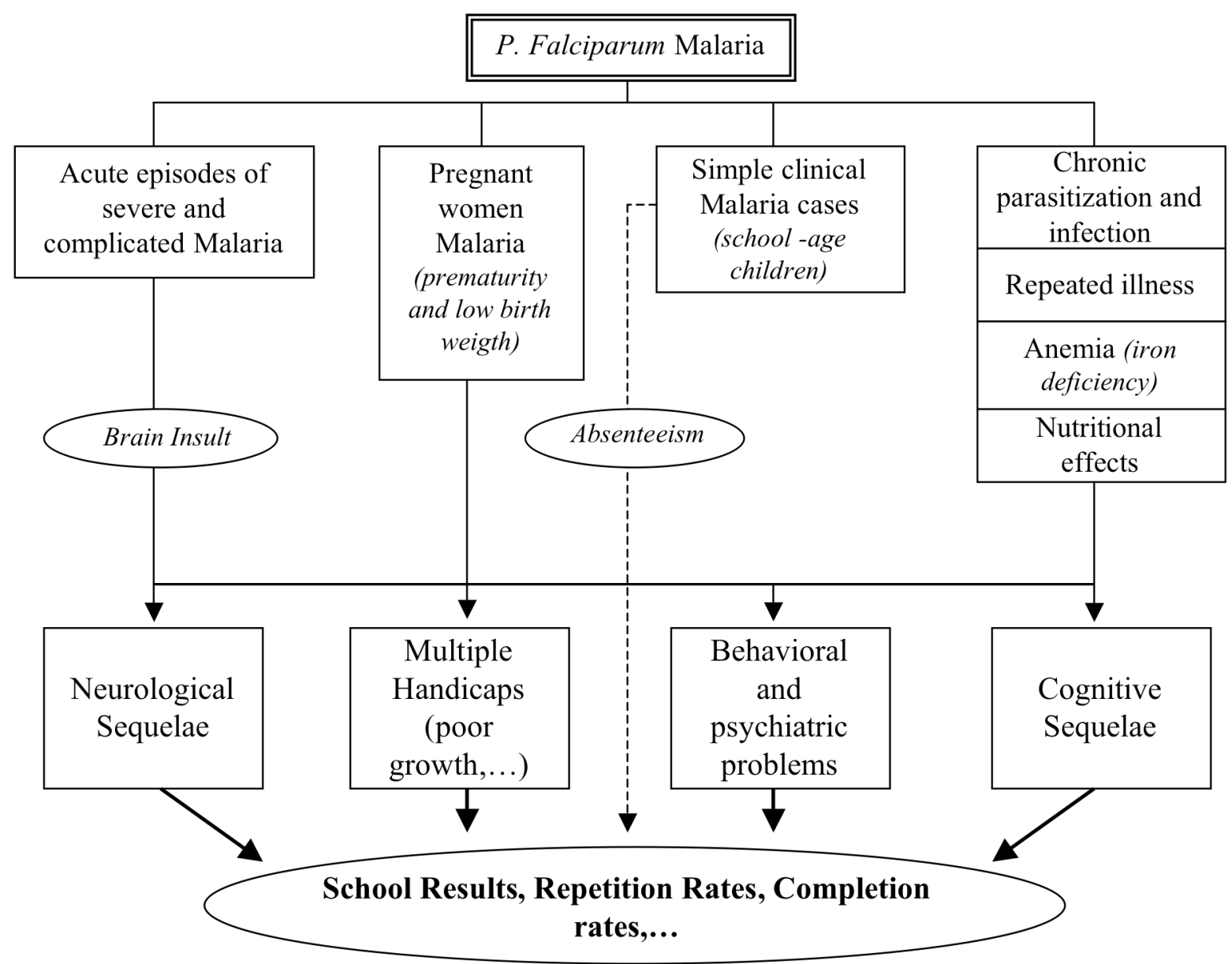




\section{Conceptual framework of the study}

Cross-country literature on the determinants of school quality tends to focus on education resources. Increasing investments in basic education has been seen as a key strategy to achieving the Education For All (EFA) goals (World Education Forum, 2000). Nevertheless, money does not seem to solve everything. In a recent paper, Samer Al-Samarrai (2006) found that the link between resources and educational outputs is weak. Increases in expenditure in primary education alone are unlikely to be sufficient to achieve the education millennium development goals. Other variables such as the effectiveness of the public expenditure management system, household spending and the composition of public education spending may explain this weak link. In this paper, we explore another potential important factor that can influence schooling quality in developing countries and may contribute to make expenses in primary education ineffective. We use the dataset from Samer Al-Samarrai (2006) for 1996 to estimate in a cross-country regression framework the impact of an index of malaria endemicity for 1994 on repetition rates and completion rates in 1996. The worldwide malaria endemicity has not decreased during the 90's. Moreover, the effects of malaria on education are relatively diffuse in time because of various socioeconomic externalities associated with the disease and a mixture of short and long-term direct effects. Hence we can reasonably hope to find interpretable results with this period of analysis. We control for other variables already used in the literature on the determinants of primary education quality. One difference in our work is that we introduce a proxy for general child health conditions, climate variables and governance indicators in the model.

The relationship between school outputs and inputs is generally analysed with an education production function ${ }^{4}$. Nevertheless, health conditions and particularly diseases that alter cognitive and learning abilities like malaria are not taken into account in this framework. We then define the education production function as:

$$
\text { (1) } Q=Q(F, R, H)+\varepsilon
$$

Where Q denotes schooling quality, F, family factors (principally family incomes), R, public resources used for primary education, $\mathrm{H}$, child health conditions and $\varepsilon$, unmeasured factors influencing schooling quality.

\section{DATA AND METHODOLOGY}

\section{Dependant Variable: Primary Repetition and Completion rates.}

Conceptually, education has two main qualitative goals. The first one is to develop cognitive capacities of students. The degree to which systems actually achieve this is one indicator of their quality. The second element is « education's role in encouraging learners' creative and emotional development, in supporting objectives of peace, citizenship and security, in promoting equality and in passing global and local cultural values down to future generations » (EFA, Global Monitoring Report, 2005). It is difficult to measure education quality for a broad number of countries, especially if we consider the second objective (Barro \& Lee, 2000).

\footnotetext{
${ }^{4}$ For examples of major studies making use of the production function concept see Bowles (1970), Katzman (1971), Hanushek (1979), Brown \& Saks (1986).
} 
As we are particularly interested in measuring the specific impact of malaria on cognitive and learning abilities of children, we first chose to consider primary school repetition rates which reflect this particular aspect of education quality. Indeed, despite the fact that repetition rates are sometimes affected by school and educational policies (such as national regulations), they are more directly determined by school results. The choice of this variable and the large database we dispose allow us to have a reasonable size sample with good developing countries coverage (in particular African countries) to make our regressions (from 80 to 84 observations). Other alternative indicators are test scores. Although, some cross-country studies have been undertaken using student's scores on internationally comparable tests of achievement in knowledge, the size of samples is often reduced because of limited availability of internationally comparable data. The recent efforts to define a standardized indicator from MLA (Monitoring Learning Achievement - UNESCO/UNICEF), SACMEQ (Consortium for Monitoring Educational Quality) and PASEC ("Programme d'Analyse des Systèmes Educatifs de la CONFEMEN") still include a small sample of countries. Primary repetition rates are defined as the proportion of pupils enrolled in a given grade at a given school-year at primary level who study in the same grade in the following school-year (UNESCO).

In order to take into account other effects of malaria on school results we also use the primary completion rates as an alternative dependent variable ${ }^{6}$. The choice of this variable gives us a smaller size sample due to the lack of data for both the explained and the explanatory variables in the models but still with good developing and African countries coverage (from 54 to 55 observations). Primary completion rates are defined as the total number of students (of any age) in the last grade of primary school, minus the number of repeaters in that grade, divided by the total number of children of official graduation age (World Bank).

Repetition and completion rates have been frequently used to compare school outcomes across countries in international monitoring reports.

\section{The P. falciparum malaria index}

A major problem when assessing the economic cost of malaria - at the macroeconomic level as well as at the microeconomic one - is to measure the exposure to malaria risk and the severity of the disease (Audibert et al., 2003). This is clearly due to the lack of data on malaria incidence. As we said above, different methodological and technical barriers impede to measure with precision the number of malaria cases.

As a proxy of child malaria morbidity, we use the index described in Sachs \& Gallup (2001) defined as the fraction of population at risk of contracting falciparum malaria in a country for 1994. Of course, it would have been better to use high-quality estimates of malaria child morbidity or mortality. Nevertheless, as there are so many problems relative to the measurement of the number of malaria cases, we consider this index as the best available measure at the macroeconomic level.

As we said, costs in terms of education are expected to differ with the level of endemicity. We can distinguish three main situations that will have different costs in terms of human capital and basic education at the macroeconomic level in our study. In highly endemic regions (where the fraction of population at risk of contracting falciparum malaria is high), mortality and morbidity mainly occurs among children aged from 4 months to five years and pregnant women. We should then expect in these areas a bigger impact of malaria on primary school quality and school performances through the channels we already comment in the

\footnotetext{
${ }^{6}$ See Samer Al Samarrai (2006) for a discussion on the conceptual problems linked with the use of completion rates.
} 
previous section (Figure 1) and because of the other external effects associated with the disease. By contrast, in regions where malaria transmission is less stable, where herd immunity is less, malaria and severe malaria can affect people of all ages but less frequently (mainly during epidemics or seasonal variations). Educational impacts are expected to be smaller. In areas free of malaria, there will be obviously no impact.

In this paper, we will consider that a country is highly endemic when the $P$. falciparum malaria index is greater than 0,5 .

\section{Other Independent Variables}

Three variables of resources that have been identified previously as potential determinants of education outcomes in the literature are used to take into account the impact of public spending on repetition rates: primary current expenditure per pupil (PPP), public current expenditure in primary education as a percentage of GNP, primary school pupil-teacher ratio.

Income per capita is also included in the regressions for two main reasons. On the one hand, many studies have shown that countries with higher income have better primary education quality. Indeed, income per capita may be interpreted as a proxy for parents' income (Barro \& Lee, 2000). On the other hand, malaria and income levels are intimately connected and our falciparum malaria index could just be a proxy for poverty.

Level of urbanisation, another explanatory variable that is a potential influential factor of primary repetition and completion rates, is included in the model. Indeed, in urban areas, school results are expected to be higher because travel costs linked with school attendance may be lower than in urban areas, children can have a better access to educational services or better general conditions to work especially in developing countries (electricity for instance).

As the literature already stressed it, effectiveness of the public expenditure management system could explain the weak link between resources and education quality (see for instance Reinikka \& Svensson, 2004). In order to control for this factor we include in the regressions one measure of governance quality developed by Kaufmann et al. (2006): "government effectiveness 1996". Regression (4) of Table A2 also includes a measure of control of corruption for 1996. The Worldwide Governance Indicators are a compilation of information and perceptions from diverse groups of respondents but have to be seen as proxies of the complex phenomenon of governance. We do not pretend here to answer to the particular question of the impact of the quality of management system on education outcomes but to catch only the influential effects of these factors on our dependant variables, ceteris paribus.

Malaria could also be a proxy for a range of other variables, principally general health conditions, particularly child health conditions, climate and geographical location. Therefore, the regressions given in Table 1 and 2 include the under-5 mortality rate (as a proxy for child health conditions) and the percent of land area in subtropics and tropics (Sachs \& Gallup, 2001). These last two variables allow us to control for climate, ecological conditions and diseases associated with tropical and subtropical location that could drive our coefficient estimates on the falciparum malaria index. As an alternative measure of geographical location, regression (1) and (5) in Table A2 include regional dummies.

\section{Descriptive statistics}

Descriptive statistics, sources and definitions of the variables used in the regressions can be found in Table A1. Simple correlations between variables are given in Table A2. As an example, take the 125 observations available for both the primary repetition rate in 1996 and the falciparum malaria index in 1994. Thirty-six countries of the 125 countries, or $29 \%$, have intensive malaria (29 are African countries). Ranking the 125 countries by primary repetition 
rate, 25 of the 36 countries with severe malaria (69\%) are in the bottom half of the ranking. A first look at the data lets us think however that malaria could only be a proxy for geographic location or other variables. In the next subsection we detail the methodology used in the study to explore the link between malaria and school results and treat the possible sources of errors.

\section{Methodology}

We begin by estimating the regressions using Ordinary Least Squares (OLS). Standard errors are adjusted for heteroscedasticity in all cases. In this first step, we consider all the available observations. Outlying observations are not automatically mistakes in data entry and can provide important economic information by increasing variation in explanatory variables. In addition to these regressions, we also analyse how robust the OLS results given in Table 1 and 2 are to different estimation techniques.

Firstly, this paper assess whether the coefficient estimate on the malaria index suffer from endogeneity bias (due to measurement errors or two-way causation principally but also omitted variables). The falciparum Malaria index can clearly suffer from measurement errors. It is also possible that low education levels have a negative impact on malaria eradication directly or through other variables like income levels, general health conditions... Therefore countries with bad educational outcomes will have more difficulties to fight against malaria. To correct for this bias, we use a spatial index of the stability of malaria transmission ${ }^{6}$ based on the interaction of climate with the dominant biologic properties of vector Anopheles of malaria (biting activity, proportion of blood meal taken from human hosts, daily survival of the vector, duration of the transmission season and of extrinsic incubation). This interaction determines vectorial capacity and explains a great part of the force, the stability and the regional variation of malaria transmission (Kiszewski et al., 2004). This index is measured on a highly disaggregated level and then averaged for the entire country weighted by population. The total number of countries in which malaria is endemic or potentially endemic has been divided into 260 different regions with their particular characteristics (to represent the diversity of habitats) and 34 vector Anopheles were considered as dominant. Because it is built upon climatological and vector characteristics, "Malaria Ecology" is exogenous to public health interventions and economic conditions. There is no reason to think that the ecologybased distribution of malaria mosquito vectors and the variation of their biologic properties are a cause of bad educational outcomes apart from the direct influence of malaria. The variable is therefore a good instrument for the falciparum malaria index. A similar instrument has already been used by Sachs \& Gallup (2001). The first stage regression of the falciparum Malaria index on the instrument ("Malaria Ecology") has a $\mathrm{R}^{2}$ of 0.56 .

Secondly, because of the sample size, we can only introduce a limited number of control variables to isolate the causal effect of the falciparum malaria index. The specification models presented in Table 1 and 2 already include a relatively high number of independent variables. Introducing more variables may lead to a "small sample size problem" and multicollinearity can increase the variance of our unbiaised estimators. Therefore, we present different specifications of the regression model with a restricted number of independant variables and a higher size sample (from 85 to 117 observations for regressions with repetition rates and from 56 to 73 observations for regressions with completion rates). We control separately for different factors by including in each regression successively a set of variables for geographical and climate characteristics, variables for health conditions, governance indicators and education resources (Table A3).

\footnotetext{
${ }^{6}$ Details about the underlying index called "Malaria Ecology" can be found on the web page of J. Sachs on malaria at The Earth Institute at Columbia University and in Kiszewski et al. (2004).
} 
Thirdly, OLS regressions assume that the residual are independent. It is very possible that the primary repetition rates within each subcontinent may not be independent and this could lead to residuals that are not independent within subcontinents. We hence allow regressions observations to be clustered into subcontinents to take into account the probable spatial correlation of observations within subcontinents (Table A4).

Fourthly, we explore whether our OLS and 2SLS results are driven by influential observations or not. OLS is susceptible to outlying observations because it minimizes the sum of squared residuals. Individual country with large residual and high leverage are identified and dropped for each regression ${ }^{7}$. From 8 to 11 countries have been identified as outliers in the regressions and dropped (Table A5).

\section{RESULTS}

\section{OLS and 2SLS Regressions Results}

The results from the regression analysis for primary repetition and completion rates are presented respectively in Table 1 and 2. In each case, regressions (1) to (3) give OLS regressions results. Three models are reported to take into account different options chosen in the literature. The first model only includes public current expenditure in primary education ( $\%$ of GNP) as a measure of total school resources. Regression (2) includes jointly public current expenditure in primary education ( $\%$ of GNP) and primary current expenditure per pupil (PPP). Regression (3) includes the last two resources variables and the primary pupilteacher ratio. An increase in total school resources may not lead to an increase in student achievement whereas components of school expenditures allocated to provide students with more school resources (instructional materials for instance) or to lower pupil-teacher ratios could raise student school results. Regressions (4) to (6) give the corresponding Two Stages Least Squares (2SLS) regressions results. The same three models are reported to compare our results with the OLS regressions. ${ }^{8}$

There appears to be a very strong relationship between the falciparum malaria index and the primary repetition and completion rates. The positive coefficient on the malaria index $(0.096 ; t=0.039)$ in regression (1) of Table 1 indicates that countries with intensive malaria have repetition rates in primary education $9 \%$ higher than countries without malaria, ceteris paribus. A one standard deviation increase in the falciparum malaria index is associated to a 0.43 standard deviation increase in primary repetition rates. The negative coefficient on the malaria index $(-0.295 ; \mathrm{t}=0.087)$ in regression (1) of Table 2 indicates that countries with intensive malaria have primary completion rates $29 \%$ lower than countries without malaria, ceteris paribus. A one standard deviation increase in the falciparum malaria index is associated to a 0.47 standard deviation decrease in primary completion rates.

The coefficient estimates on the malaria index are significantly different from 0 (at the 5\% level) in regression (1) and (2) of Table 1. In regression (3) of Table 1, the P. value of the coefficient estimate is 0.13 and the value of the coefficient estimate is lower than in the previous regressions. This may be due to the high correlation between the falciparum malaria index and the pupil-teacher ratio within the sample (0.73). However, the corresponding Instrumental Variable estimation, given in regression (6) of Table 1, shows that the impact of

\footnotetext{
${ }^{7}$ Studentized residuals and leverages were examined as a first approach for identifying outliers and observations that have potential great influence on regression coefficient estimates. Next, DFIT statistic was used as an overall measure of influence.

${ }^{8}$ Each school resources variable has also been included separately. These results (not reported here but available from the author on request) do not alter the main findings of this paper.
} 
malaria is still significant, positive and high. In all OLS regressions of Table 2 , the coefficient estimates on the malaria index are significantly different from zero, negative and relatively stable.

Section 3 suggested that the falciparum malaria index may be endogenous and explained that instrumental variable estimation can be used to account for this problem. Two stages least squares regressions are given in column (4) to (6) of Table 1 and 2. We use the "Malaria Ecology" previously described as an instrument for the falciparum malaria index. If there were a reverse causation between the malaria index and primary repetition and completion rates, the coefficient estimates on the malaria index reported in columns (1) to (3) would be positively biased in Table 1 and negatively biased in Table 2. After correcting for the possible endogeneity of the falciparum malaria index, the absolute value of the estimated effect of malaria on repetition and completion rates is higher than our previous results and still statistically significant in all regressions. This generally occurs when the endogenous variable suffers from measurement errors and the falciparum malaria index is actually relatively crude. Therefore, the 2SLS regression analysis confirms that the link between falciparum malaria and primary repetition and completion rate is strong. The positive coefficient on the malaria index $(0.180 ; \mathrm{t}=0.060)$ in regression (4) of Table 1 indicates that countries with intensive malaria have repetition rates in primary education $18 \%$ higher than countries without malaria, ceteris paribus. The negative coefficient on the malaria index $(-0.543 ; \mathrm{t}=0.183)$ in regression (4) of Table 2 indicates that countries with intensive malaria have primary completion rate 54\% lower than countries without malaria, ceteris paribus. As 2SLS and OLS estimates on the falciparum malaria index differ significantly (because of measurement errors on the malaria index), the 2SLS estimator is more efficient than the OLS estimator. Therefore, we will now focus on regressions (4) to (6) of Table 1 and 2 for the analysis.

GNP per capita is only significant in regression (6) of Table 1 and its impact on primary repetition rate is small and positive. Coefficient estimates of GNP per capita in regressions for completion rates are not significantly different from zero. These results suggest that income per capita do not have a strong impact on primary repetition and completion rates.

Tropical and subtropical location does not appear to have a significant impact on primary repetition and completion rates. It could be argued that the impact of malaria on educational outcomes reflects the influence of a particular region and not the isolated effect of malaria. For example, Sub-Saharan Africa has in average high levels of malaria, high repetition rates and relatively low repetition rates. Hence, the malaria index could just be a proxy for SubSaharan Africa. Regression (1) and (5) of Table A3 include regional dummies (South Asia, East Asia, Sub-Saharan Africa, Middle East and North Africa, and Latin America and the Caribbean). The results are globally unchanged.

Whereas it was positively and significantly associated with repetition rates in OLS regressions, the Under-5 mortality rate does not appear to have a significant impact on repetition or completion rates in 2SLS regressions. In all 2SLS regressions of Table 1 and 2, the coefficient estimates on the Under-5 mortality rate are not significantly different to zero.

Level of urbanisation and the Governance indicator have no significant impact on the educational outcomes under study here.

The coefficient estimates on public current primary expenditure ( $\%$ of GNP) is negative in all regressions of Table 1. It is positive in regressions (4) and (6) and negative in regression (5) of Table 2 but never significantly different from 0 . This insignificant effect of total educational spending on repetition or completion rates suggests that an increase in total school resources itself may not lead to an increase in student achievement. This conclusion is in accordance with Hanushek (1995) and Samer Al Samarrai (2006). There is no systematic relationship between school performance and general measure of school resources. 
When regressions include two school variables (primary expenditure per pupil and public current primary expenditure as a proportion of GNP) the results are not dramatically changed. Results suggest that primary expenditure per pupil is also an insignificant determinant of repetition and completion rates, ceteris paribus.

Nevertheless, when the regressions include the three school variables, the pupil-teacher ratio is positively and significantly (at the $1 \%$ level) associated with repetition rates in regression (6) of Table 1. This result is in keeping with Barro and Lee (2001) conclusions about the link between repetition rates and pupil-teacher ratio. A lower pupil-teacher ratio is estimated to improve repetition rates and test scores. Components of school expenditures allocated to lower the pupil-teacher ratio will reduce primary repetition rates whereas the other resources variables still have no significant impact. Nevertheless, the literature remains ambiguous on this point (Samer Al Samarrai, 2006). Moreover, the pupil-teacher ratio is not significant in the primary completion rate regression (regression (6) of Table 2). Therefore, as in the literature, there seems to be an ambiguous relationship between educational outcomes and commonly measured school resources. Nevertheless, as this question is not the primary focus of our study we will now concentrate our efforts on testing the robustness of the coefficient estimates on the malaria index. 
TABLE 1: OLS and 2SLS Results for Primary Repetition Rate

\begin{tabular}{|c|c|c|c|c|c|c|}
\hline & \multicolumn{6}{|c|}{ Dependant variable is Primary Repetition Rate (1996) } \\
\hline & \multicolumn{3}{|c|}{ OLS } & \multicolumn{3}{|c|}{$2 S L S$} \\
\hline $\begin{array}{l}\text { Falciparum Malaria index } \\
1994\end{array}$ & $\begin{array}{l}0.096 * * \\
(0.039)\end{array}$ & $\begin{array}{l}0.102^{* *} \\
(0.045)\end{array}$ & $\begin{array}{c}0.066 \\
(0.043)\end{array}$ & $\begin{array}{l}0.180^{* * *} \\
(0.060)\end{array}$ & $\begin{array}{l}0.185^{* * *} \\
(0.059)\end{array}$ & $\begin{array}{l}0.111^{*} \\
(0.067)\end{array}$ \\
\hline $\begin{array}{l}\text { Log GNP per capita PPP } \\
(\$ \text { constant } 95)\end{array}$ & $\begin{array}{c}0.023 \\
(0.015)\end{array}$ & $\begin{array}{l}0.034^{*} \\
(0.019)\end{array}$ & $\begin{array}{l}0.037^{* *} \\
(0.017)\end{array}$ & $\begin{array}{c}0.019 \\
(0.016)\end{array}$ & $\begin{array}{c}0.030 \\
(0.020)\end{array}$ & $\begin{array}{l}0.034^{* *} \\
(0.017)\end{array}$ \\
\hline Subtropics (\% land area) & $\begin{array}{c}0.038 \\
(0.029)\end{array}$ & $\begin{array}{c}0.026 \\
(0.029)\end{array}$ & $\begin{array}{c}0.013 \\
(0.030)\end{array}$ & $\begin{array}{c}0.021 \\
(0.034)\end{array}$ & $\begin{array}{c}0.009 \\
(0.035)\end{array}$ & $\begin{array}{c}0.006 \\
(0.034)\end{array}$ \\
\hline $\begin{array}{l}\text { Log Urban Pop (\% total } \\
\text { pop) }\end{array}$ & $\begin{array}{c}0.031 \\
(0.032)\end{array}$ & $\begin{array}{c}0.024 \\
(0.036)\end{array}$ & $\begin{array}{c}0.018 \\
(0.032)\end{array}$ & $\begin{array}{c}0.042 \\
(0.034)\end{array}$ & $\begin{array}{c}0.039 \\
(0.038)\end{array}$ & $\begin{array}{c}0.026 \\
(0.035)\end{array}$ \\
\hline $\begin{array}{l}\text { Log Under } 5 \text { Child } \\
\text { mortality } 1995\end{array}$ & $\begin{array}{c}0.053^{* * *} \\
(0.017)\end{array}$ & $\begin{array}{l}0.049^{* * *} \\
(0.017)\end{array}$ & $\begin{array}{l}0.034^{* *} \\
(0.015)\end{array}$ & $\begin{array}{c}0.029 \\
(0.023)\end{array}$ & $\begin{array}{c}0.026 \\
(0.023)\end{array}$ & $\begin{array}{c}0.025 \\
(0.019)\end{array}$ \\
\hline $\begin{array}{l}\text { Log Publ Expend in Prim } \\
\text { Educ (\% GNP) } 1996\end{array}$ & $\begin{array}{l}-0.019 \\
(0.014)\end{array}$ & $\begin{array}{l}-0.013 \\
(0.016)\end{array}$ & $\begin{array}{l}-0.015 \\
(0.014)\end{array}$ & $\begin{array}{l}-0.017 \\
(0.014)\end{array}$ & $\begin{array}{l}-0.012 \\
(0.017)\end{array}$ & $\begin{array}{l}-0.014 \\
(0.015)\end{array}$ \\
\hline $\begin{array}{l}\text { Log Primary expenditure } \\
\text { per pupil PPP } 1996\end{array}$ & - & $\begin{array}{l}-0.012 \\
(0.011)\end{array}$ & $\begin{array}{l}-0.007 \\
(0.010)\end{array}$ & - & $\begin{array}{l}-0.010 \\
(0.014)\end{array}$ & $\begin{array}{l}-0.007 \\
(0.011)\end{array}$ \\
\hline Intercept & $\begin{array}{l}-0.530^{* * *} \\
(0.187)\end{array}$ & $\begin{array}{l}-0.470^{* *} \\
(0.203)\end{array}$ & $\begin{array}{c}-0.740^{* * *} \\
(0.204)\end{array}$ & $\begin{array}{l}-0.466^{\star *} \\
(0.197)\end{array}$ & $\begin{array}{l}-0.432^{* *} \\
(0.221)\end{array}$ & $\begin{array}{c}-0.692^{* * *} \\
(0.207)\end{array}$ \\
\hline Number ofobservations & 84 & 82 & 80 & 84 & 82 & 80 \\
\hline$R$ squared & 0.51 & 0.52 & 0.59 & 0.46 & 0.48 & 0.58 \\
\hline $\begin{array}{l}\text { Notes: } \\
\text { 1. Robust standard errors, } \\
\text { 2. Standard errors in paren } \\
\text { 3. }{ }^{* * *} \text { denotes statistical si }\end{array}$ & $\begin{array}{l}\text { usted for } r \\
\text { sis } \\
\text { cance at } t\end{array}$ & $\begin{array}{l}\text { cedasticit } \\
\text { level, }{ }^{* *} \mathrm{a}\end{array}$ & $\begin{array}{l}\text { sed in all c } \\
\text { \% level, * a }\end{array}$ & level. & & \\
\hline
\end{tabular}


TABLE 2: OLS and 2SLS Results for Primary Completion Rate

\begin{tabular}{|c|c|c|c|c|c|c|}
\hline & \multicolumn{6}{|c|}{ Dependant variable is Primary Completion Rate (1996) } \\
\hline & \multicolumn{3}{|c|}{ OLS } & \multicolumn{3}{|c|}{$2 S L S$} \\
\hline $\begin{array}{l}\text { Falciparum Malaria } \\
\text { index } 1994\end{array}$ & $\begin{array}{c}-0.295^{* * *} \\
(0.087)\end{array}$ & $\begin{array}{c}-0.325^{* * *} \\
(0.102)\end{array}$ & $\begin{array}{l}-0.222^{*} \\
(0.112)\end{array}$ & $\begin{array}{c}-0.543^{* * *} \\
(0.184)\end{array}$ & $\begin{array}{c}-0.554^{* * *} \\
(0.188)\end{array}$ & $\begin{array}{l}-0.480^{\star} \\
(0.264)\end{array}$ \\
\hline $\begin{array}{l}\text { Log GNP per capita } \\
\text { PPP ( } \$ \text { constant } 95)\end{array}$ & $\begin{array}{l}-0.003 \\
(0.051)\end{array}$ & $\begin{array}{l}-0.040 \\
(0.045)\end{array}$ & $\begin{array}{l}-0.053 \\
(0.441)\end{array}$ & $\begin{array}{c}0.029 \\
(0.064)\end{array}$ & $\begin{array}{c}0.002 \\
(0.061)\end{array}$ & $\begin{array}{l}-0.009 \\
(0.068)\end{array}$ \\
\hline $\begin{array}{l}\text { Subtropics (\% land } \\
\text { area) }\end{array}$ & $\begin{array}{c}0.008 \\
(0.075)\end{array}$ & $\begin{array}{c}0.045 \\
(0.072)\end{array}$ & $\begin{array}{c}0.096 \\
(0.076)\end{array}$ & $\begin{array}{c}0.013 \\
(0.086)\end{array}$ & $\begin{array}{c}0.047 \\
(0.082)\end{array}$ & $\begin{array}{c}0.065 \\
(0.090)\end{array}$ \\
\hline $\begin{array}{l}\text { Log Urban Pop ( } \% \text { total } \\
\text { pop) }\end{array}$ & $\begin{array}{c}0.072 \\
(0.053)\end{array}$ & $\begin{array}{l}0.104^{*} \\
(0.057)\end{array}$ & $\begin{array}{l}0.124^{* *} \\
(0.057)\end{array}$ & $\begin{array}{c}0.042 \\
(0.058)\end{array}$ & $\begin{array}{c}0.053 \\
(0.062)\end{array}$ & $\begin{array}{c}0.068 \\
(0.068)\end{array}$ \\
\hline $\begin{array}{l}\text { Log Under } 5 \text { Child } \\
\text { mortality } 1995\end{array}$ & $\begin{array}{l}-0.095 \\
(0.063)\end{array}$ & $\begin{array}{l}-0.079 \\
(0.065)\end{array}$ & $\begin{array}{l}-0.078 \\
(0.064)\end{array}$ & $\begin{array}{c}0.000 \\
(0.098)\end{array}$ & $\begin{array}{l}0.000 \\
0.098\end{array}$ & $\begin{array}{l}-0.012 \\
(0.108)\end{array}$ \\
\hline $\begin{array}{l}\text { Log Publ Expend in } \\
\text { Prim Educ (\% GNP) } \\
1996\end{array}$ & $\begin{array}{c}0.018 \\
(0.030)\end{array}$ & $\begin{array}{c}0.003 \\
(0.032)\end{array}$ & $\begin{array}{c}0.014 \\
(0.033)\end{array}$ & $\begin{array}{c}0.001 \\
(0.030)\end{array}$ & $\begin{array}{l}-0.002 \\
(0.032)\end{array}$ & $\begin{array}{c}0.002 \\
(0.036)\end{array}$ \\
\hline $\begin{array}{l}\text { Log Primary } \\
\text { expenditure per pupil } \\
\text { PPP } 1996\end{array}$ & - & $\begin{array}{c}0.036 \\
(0.024)\end{array}$ & $\begin{array}{c}0.028 \\
(0.023)\end{array}$ & - & $\begin{array}{c}0.023 \\
(0.027)\end{array}$ & $\begin{array}{r}0.022 \\
(0.026)\end{array}$ \\
\hline Intercept & $\begin{array}{c}0.991^{*} \\
(0.561)\end{array}$ & $\begin{array}{c}0.797 \\
(0.605)\end{array}$ & $\begin{array}{c}1.35^{*} \\
(0.204)\end{array}$ & $\begin{array}{c}0.497 \\
(0.763)\end{array}$ & $\begin{array}{c}0.483 \\
(0.783)\end{array}$ & $\begin{array}{c}0.737 \\
(1.071)\end{array}$ \\
\hline Number ofobservations & 55 & 54 & 54 & 55 & 54 & 54 \\
\hline$R$ squared & 0.79 & 0.80 & 0.82 & 0.75 & 0.80 & 0.79 \\
\hline
\end{tabular}

1. Robust standard errors, adjusted for heteroscedasticity are used in all cases.

2. Standard errors in parenthesis

3. ${ }^{* * *}$ denotes statistical significance at the $1 \%$ level, ${ }^{* *}$ at the $5 \%$ level, ${ }^{*}$ at the $10 \%$ level.

5. Instrument used in two stage least squares is malaria ecology which is an ecological-based spatial index of the stability of malaria transmission. The index is measured on a highly disagregated sub-national level (Kiszewski \& al - 2004). 


\section{Robustness Tests}

Results presented in Table 1 and 2 also appear to be robust to different tests already detailed in the previous section.

Regressions in Table A3 present alternative specification models with a reduced number of variables. We control for different sets of independent variables. Only the 2SLS regressions have been presented. All regressions include the falciparum malaria index and GNP per capita. We control successively and separately for geographical (regional dummies instead of climate variables), variables for health conditions, governance indicators (control of corruption and government effectiveness) and educational resources. Using these specification models does not alter the main conclusions of this paper. The regional dummy variable that appears to play significant role on the 2SLS regressions with repetition rates is Latin America and the Caribbean. These countries, on average, have higher primary repetition rates than other countries, after controlling for the variables included in the model. No dummy variable appears to play significant role on the 2SLS regressions with repetition rates is Latin America and the Caribbean. Malaria could also be a proxy for a range of tropical diseases that are not adequately controlled for by Under-5 child mortality (1995), tropical and subtropical location. To assess whether other diseases were responsible for the correlation of malaria with primary repetition and completion rates, we include jointly two relevant indicators for the time period under study here: an average of the proportion of the population living in areas with dengue fever from 1975 to 1995 and an estimating fraction of the population at risk of contracting yellow fever for 1996 (Sachs \& Gallup, 2001). Descriptions and sources of these variables are given in Table A1. Results are given in regressions (2) and (6) of Table A3. Unfortunately we do not have indicators neither for other tropical diseases nor for the acquired immunodeficiency syndrome (AIDS) at the macroeconomic level for 1996. As the spread of AIDS has evolved very quickly, we have not included recent data of this burden in the regressions. However, we do not think that our conclusions will be changed with the inclusion of such indicator because AIDS affects education by different channels than malaria (for instance through its impact on teachers). The estimated impact of malaria remains relatively stable and statistically significant at the 5\% level for regression (2) and at the $1 \%$ level for regression (6). The two tropical diseases have no significant correlation with repetition and completion rates.

Table A3 shows that our results do not change dramatically when observations are clustered within subcontinents. The 2SLS results are nearly the same of those presented in Table 1 and 2. Therefore, we cannot reject the assumption that the residuals are independent.

Table A4 shows that our conclusions are not modified when influential observations are dropped. The size and significance of the coefficient estimates on the falciparum malaria index change only slightly.

\section{DISCUSSION AND CONCLUSIONS}

Our cross-country analysis has shown that the link between the level of falciparum malaria endemicity and primary repetition rates is strong and positive. The link between the level of falciparum malaria endemicity and primary completion rates is strong and negative. These results suggest that malaria contributes to impede children's human capital accumulation.

Nevertheless, one may be careful when interpreting the results presented in the previous section. Why is there such a strong link? As we already explained it in section 2, malaria affects specifically child's cognitive and learning abilities and consequently school results. Our conjecture was that high repetition rates and low completion rates reflect particularly bad 
school results. Therefore, the strong link between malaria and primary repetition and completion rates reflects the impact of malaria on school results and does not imply that similar relation exists systematically between malaria and other educational outcomes. We did not explore here the relationship between falciparum malaria and other educational indicators. Moreover, malaria is a complex economic and social phenomenon. It is very difficult to dissociate the direct medical impact of the disease from its numerous effects on society and human organization. In addition to its medical effects, the behavioural and social aspects linked with malaria may explain part of the estimated impact of malaria on repetition and completion rates given in this paper.

A major problem when assessing the impact of malaria on education is also the lack of good data. Our conclusions are valid in the limitation of data precision and availability. Some variables that may be expected to influence education outcomes or bias the coefficient values of the malaria index were not included because of the lack of cross-country data. We tried to account for this problem using different specifications of the regression model and different estimation techniques but it is still possible that variables correlated with the malaria index have been omitted. For instance, malaria is associated with other tropical diseases. We have not control for a large number of tropical disease because of the lack of appropriate data for the time period under study here.

Finally, the conclusions we made are also valid only at the macroeconomic stage and are not a substitute for detailed country analysis or case studies. Microeconomic evaluations of the impact of malaria on school performances may differ from macroeconomic previsions.

However, our results on the link between falciparum malaria and primary repetition rates suggest that the achievement of the education millennium development goals (in particular aspects concerning education quality) will require more than just focusing on expenditure in primary education. The results have been shown to be robust to a series of tests (different specification models, controls for influential observations, different estimation techniques). In addition to that, our estimations of the impact of malaria on repetition and completion rates are not in contradiction with the micro assessments. For instance, the impact of malaria on primary repetition rates (countries with intensive malaria have repetition rates in primary education from $11 \%$ to $18 \%$ higher than countries without malaria, ceteris paribus) is in accordance with the micro estimations of the impact of malaria on test scores (see section 2). Of course it is very difficult to quantify very precisely this impact because of the low precision of the data used here but these results seem to provide a good idea of the burden at the macroeconomic stage. Regressions with completion rates also suggest that there are other externalities linked with the disease, as the impact is even higher.

It does not imply that resources in education are unnecessary but that increasing resources in education or improving education resources management alone are unlikely to be sufficient. To the question "What are the most effective ways to increase primary school student learning?", we answer that diseases that alter cognitive capacities of children such as malaria should be taken into account much more seriously. This conclusion seems to be obvious but has not been the subject of careful researches in developing countries. Improving educational outcomes and especially school results in developing countries will require more attention on child health.

This paper sees the need to place emphasis on the interactions between health and education policies in developing countries. In some cases, it might be more effective to invest in some specific health programs to improve educational quality rather than increasing public expenditure in education. Reciprocally, improving education could be one of the components that will improve the quality of interventions to prevent diseases like malaria. The impacts of school-based malaria control programs are still little known whereas education is one of the determinants of knowledge about malaria. Sharma et al. (2003) have shown that improvement 
in literacy and educational status will help in increasing the level of knowledge about various aspect of malaria. Knowledge about malaria and prevention measure is also one of the determinants of the use of insecticide-treated nets. It is possible to educate individuals about malaria and to implement net impregnation services with limited resources (Rhee et al., 2005). One challenge remains in understanding how this could be made at large-scale, as only local experiences have succeeded in this task. Specific education expenditure to face malaria should be examined in addition to health policies. Research should pay more attention on these aspects in order to clarify, classify and quantify the needs and avoid wasting resources in the fight against malaria.

\section{ACKNOWLEDGEMENTS}

The author is grateful for comments from M. Audibert, J.C. Berthélémy, S. Poncet, all the participants to the Séminaire d'économie CES (Paris), and particularly from S. Al-Samarrai who accepted to provide part of the database for this study. The author remains solely responsible for any errors.

Correspondence to: Josselin Thuilliez, TEAM-CNRS, Pôle Développement - Bureau 225, Maison des Sciences Economiques, 106-112 Bd de l'Hôpital 75647 Paris Cedex 13.

Email: Josselin.Thuilliez@malix.univ-paris1.fr

\section{REFERENCES}

1. Acemoglu D, Johnson S, Robinson J, "Institutional causes, Macroeconomic symptoms, volatility, crises and growth", NBER Working paper 9124, 2002.

2. Al-Samarrai S, "Achieving education for all: how much does money matter?", Journal of international development, 18, 179-206, 2006.

3. Al Serouri A.W, Grantham-McGregor S.M, Greenwood B.M, Costello A, "Impact of asymptomatic malaria parasitaemia on cognitive function and school achievement of schoolchildren in the Yemen Republic", Parasitology, 121 (337-345), 2000.

4. Audibert M, "Agricultural non-wage production and health status : a case study in a tropical environment", Journal of Development Economics, 24, 275-291, 1986.

5. Audibert M, Mathonnat J, Nzeyimana I, Henry M.C, "Rôle du paludisme dans l'efficience technique des producteurs de coton dans le nord de la Côte d'Ivoire», Revue d'Economie du Développement, volume spécial «Santé et Développement», 4, 121-148, 1999.

6. Audibert M, Mathonnat J, Henry M.C, "Social and health determinants of the technical efficiency of cotton farmers in Northern Côte d'Ivoire", Social Science and Medicine, 56, 1705-1717, 2003.

7. Audibert M, Mathonnat J, Henry M.C., "Malaria and property accumulation in rice production systems in the savannah zone of Côte d'Ivoire", Tropical Medicine and International Health, volume 8, 5, 471- 483, 2003.

8. Barlow R, "The economic effects of malaria eradication", American Economic Review, Vol 57, $\mathrm{N}^{\circ} 2$ (130-148), 1967.

9. Barro R.J, Lee J.W, "Schooling quality in a cross-section of countries", Economica, 68, 465- 488, 2001.

10. Bleakley H, "Malaria in the Americas: A Retrospective Analysis of Childhood Exposure." Documento CEDE 2006-35, Universidad de Los Andes, 2006.

11. Bowles S, "Toward an educational production function. In W.L Hanson (Eds), Education, Income and Human capital, pp. 11- 61", New York: Columbia University Press, 1970.

12. Brewster D.R, Kwiatkowski D, White N.J, "Neurological sequelae of cerebral malaria children", Lancet, 336 (1039-1043), 1990.

13. Brooker S, Guyatt H, Omumbo J, Shretta R, Drake L, Ouma J, "Situation analysis of malaria in school-aged children in Kenya - what can be done?", Parasitology Today, 16(5), 183-186, 2000. 
14. Brooker S, Clements A.C.A, Hotez P.J, Hay S.I, Tatem A.J, Bundy D.A.P, Snow W.R, "The codistribution of Plasmodium falciparum and hookworm among African schoolchildren", Malaria Journal, 5:99, 2006.

15. Brown. BW \& Saks. DH, "Measuring the effects of instructional time on student learning: evidence from the beginning teacher evaluation study", American Journal of Education, 94(4), 480-500, 1986.

16. Bryce J, Boschi-Pinto C, Shibuya K, Black R.E, Who Child Health Epidemiology Reference Group, "WHO estimates of the causes of death in children", Lancet, 365, 1147-1152, 2005.

17. Carter J.A, Murira G.M, Ross A.J, Mung'ala-Odera V, Newton C.R..J.C, "Speech and language sequelae of severe malaria in Kenyan children”, Brain Injury, vol. 17 issue 3, p²17, 2003.

18. Carter J.A, Lees. JA, Gona J.K, Murira G, Rimba K, Neville B.G.R, Newton C.R.J.C, "Severe falciparum malaria and acquired childhood language disorder", Developmental medicine and Child Neurology, 48:1 (51-57), 2006.

19. Carter J.A, Newton C.R.J.C, "The effects of Plasmodium falciparum on cognition: a systematic review", Tropical Medicine \& International Health, Vol 11, Issue 4, 386-397, 2006.

20. Carter J.A, Ross A.J, Neville. B.G.R, Obiero E, Katana K, Mung'ala-Odera V, Lees J.A, Newton C.R.J.C, "Developmental impairment following severe falciparum malaria in children", Tropical medicine and international health, 10:1 (3-10), 2005.

21. Chima R.I, Goodman C.A, Mills A, "The economic impact of malaria in Africa: a critical review of evidence", Health Policy, 63, 17-36, 2003.

22. Conly G.N, "The impact of malaria on economic development", Scientific publication 297, Pan American Health Organization, Washington, 1975.

23. Currie J, Stabile J, "Child mental Health and Human Capital accumulation: the case of ADHD", Journal of Health Economics, 25 1094-1118, 2006.

24. EDICEF/UNESCO, Mazer \& Sankalé, Guide de Médecine tropicale en Afrique et Océan indien, EDICEF, 1988.

25. Ettling M, McFarland D.A, Schultz L.J, Chitsulo L, "Economic impact of malaria in Malawian households", Tropical Medicine and Parasitology, 45:1 (74-79), 1994.

26. Fernando D, De Silva D, Carter R, Mendis K.N, Wickremasinghe R, "A randomized, doubleblind, placebo-controlled, clinical trial of the impact of malaria prevention on the educational attainment of school children", American Journal of Tropical Medicine and Hygiene, 74(3), pp. 386-393, 2006.

27. Fernando D, Gunawardena D.M, Bandara M.R.S.S, De Silva D, Carter R, Mendis K.N, Wickremasinghe A.R, "The impact of repeated malaria attacks on the school performance of children”, American Journal of Tropical Medicine and Hygiene, 69:6 (582-588), 2003.

28. Fernando D, Wickremasinghe R, Mendis K.N, Wickremasinghe A.R, "Cognitive performance at school entry of children living in malaria-endemic areas of Sri Lanka", Transaction of the Royal Society of tropical medecine and hygiene, 97, 161-163, 2003.

29. Gomes. M, "Economic and demographic research on malaria: a review of the evidence", Social science and Medicine, 37:9, 1093-1108, 1993.

30. Hanushek E.A, "Conceptual and empirical issues in the estimation of education production functions", Journal of Human Ressources, 14(3), 351-388, 1979.

31. Hanushek E.A, "Interpreting recent research on schooling in developing countries, The World Bank Research Observer, 10(2), 227-246.

32. Holding P.A, Snow R.W, "Impact of P. Falciparum malaria on performance and learning: review of evidence", American Journal of Tropical Medicine and Hygiene, 64 (1,2)S, 68-75, 2001.

33. Holding P.A, Kitsao-Wekulo P.K, "Describing the burden of Malaria on child development: What should we be measuring and how should we be measuring it?", American Journal of Tropical Medicine and Hygiene, 71(Suppl 2), 71-79, 2004.

34. Hung L.Q, De Vries P.J, Giao P.T, Nam N.V, Binh T.Q, Chong M.T, Quoc N.T.T.A, Thanh T.N, Hung L.N, Kager P.A, "Control of malaria: a successful experience from VietNam", Bulletin of the World Health Organization 80:8 (660-666), 2002.

35. Imbert P, "Criteria of severity in childhood falciparum malaria", Archives de Pédiatrie, 10 suppl $5(532 \mathrm{~s}-538 \mathrm{~s}) 2003$. 
36. Katzman M.T (1971), "The political economy of urban schools", Cambridge, MA: Harvard University Press, 1971.

37. Kelley T.L, "The effect of Malaria and Hookworm upon physical and mental development of school children”, The Elementary School Journal, Vol 18, Nº1, pp. 43-51, 1917.

38. Kere N.K, Keni J.F, Bobogare A, Weber R.H, "The economic impact of plasmodium falciparum malaria on education investment: a pacific Island case study", Southeast Asian J. Trop Med. Public Health, 24 (659-663), 1993.

39. Kihara M, Carter J.A, Newton C.R.J.C, "The effect of Plasmodium Falciparum on cognition: a systematic review", Tropical Medicine \& International Health, Apr. 2006.

40. Kiszewski A, Mellinger A, Spielman A, Malaney P, Sachs J, Sachs S.E, "A global index of the stability of malaria transmission", American Journal of Tropical Medicine and Hygiene, 71 (suppl 2), 141-146, 2004.

41. Kroeger A, Meyer R, Mancheno M, Gonzalez M, "Health education for community-based malaria control: an intervention study in Ecuador, Colombia and Nicaragua", Tropical Medicine \& International Health, 1:6 (836-846), 1996.

42. Leighton C, Foster R, Economic impacts of malaria in Kenya and Nigeria, Bethesda, Maryland: Abt Associates, Health Financing and Sustainability Project, 1993.

43. Mabiala-Babela J.R, Samba-Louaka C, Mouko A, Senga P, "Morbidité dans un service de pédiatrie du CHU de Brazaville: 12 ans après (1989-2001)", Archives de Pédiatrie, 10, 2003.

44. MacDonald G, "The economic importance of malaria in Africa", WHO/MAL/60, AFR/MAL/Conf./16, 1950.

45. Magnussen P, Ndawi B, Sheshe A.K, Byskov J, Mbwana K, "Malaria diagnosis and treatment administred by teachers in primary schools in Tanzania", Tropical Medicine and International Health, Vol.6, 273-279, 2001.

46. Mensah O.A, Kumaranayake. L, "Malaria incidence in rural Benin: does economics matter in endemic area?", Health Policy, 68:1 (93-102), 2004.

47. Newman P, Malaria eradication and population growth: with special reference to Ceylon and British Guiana, Research Series $n^{\circ} 10$, Bureau of Public Health Economics, School of Public Health, University of Michigan.

48. Okabayashi H, Thongthien P, Singhasvanon P, Waikagul J, Looareesuwan S, Jimba M, Kano S, Kojima S, Takeuchi T, Kobayashi T, "Key to success for a school-based malaria control program in primary school in Thailand", Parasitology International, 55:2 (121-126), 2006.

49. Reinikka R, Svensson J, "Local Capture: Evidence From a Central Government Transfer Program in Uganda," The Quarterly Journal of Economics, MIT Press, vol. 119(2), pages 678-704, 2004.

50. Rhee M, Sissoko M, Perry S, McFarland W, Parsonnet J, Doumbo O, "Use of insecticide-treated nets (ITNs) following a malaria education intervention in Piron, Mali: a control trial with systematic allocation of households", Malaria Journal, 4: 35, 2005.

51. Rodrik D, Rodriguez F, "Trade Policy and Economic Growth: a skeptic's guide to the crossnational evidence", Macroeconomics Annual 2000, eds. Ben Bernanke and Kenneth S. Rogoff, MIT Press for NBER, Cambridge, MA, 2001.

52. Sachs J, Malaney P, "The economic and social burden of malaria", Nature, Vol. 415, n6872, 2002.

53. Sachs J, Gallup J.L, "The economic burden of malaria", The supplement to the American Journal of Tropical Medicine \& Hygiene, vol. 64, $\mathrm{N}^{\circ} 1.2$, 85-96, 2001.

54. Sharma A.K, Aggarwal O.P, Chaturvedi S, Bhasin S.K, "Is education a determinant of knowledge about malaria among Indian tribal population?", Journal of Communicable Diseases, 35:2 (109117), 2003.

55. Snow R.W, Trape J.F, Marsh K, "The past, present and future of childhood malaria mortality in Africa”, TRENDS in Parasitology, Vol.17, №12, 2001.

56. UNESCO. EFA Global Monitoring Report. Education for all: The Quality Imperative, UNESCO: Paris, 2005.

57. UNESCO. EFA, Education for all: Paving the way for action, UNESCO: Regional office in Dakar, 2005.

58. Watts S, "British Development policies and malaria in India 1897-1929", Past and Present, $\mathrm{n}^{\circ} 165$, pp. 141-181, 1999. 
59. WHO, RBM, UNICEF, World Malaria Report 2005, World Health Organization and UNICEF, Geneva, 2005.

60. Worrall E, Morel C, Yeung S, Borghi J, Webster J, Hill J, Wiseman V, Mills A, "The economics of malaria in pregnancy - a review of the evidence and research priorities", Lancet Infectious Diseases, 7, 156-168, 2007. 
APENDIX

TABLE A1: Definition, sources and descriptive statistics

\begin{tabular}{|c|c|c|c|c|c|c|c|}
\hline \multirow[t]{2}{*}{ Variables } & \multirow[t]{2}{*}{ Definition } & \multirow[t]{2}{*}{ Source } & \multicolumn{5}{|c|}{ Descriptive Statistics } \\
\hline & & & Obs & Mean & Std Dev & Min & $\operatorname{Max}$ \\
\hline $\begin{array}{l}\text { Primary repetition rate } \\
1996\end{array}$ & $\begin{array}{l}\text { \% of repeaters in primary education, } 1996 \text { (some values are for } \\
\qquad 1995 \text { or } 1997)\end{array}$ & $\begin{array}{l}\text { Al Samarrai S (2006) from UNESCO } 2001 \text { \& } \\
\text { UNESCO EFA } 2000\end{array}$ & 147 & 0.06 & 0.08 & 0.00 & 0.35 \\
\hline $\begin{array}{l}\text { Primary completion } \\
\text { rate } 1996\end{array}$ & $\begin{array}{l}\text { Total number of students (of any age) in the last grade of primary } \\
\text { school, minus the number of repeaters in that grade, divided by } \\
\text { the total number of children of official graduation age, } 1996\end{array}$ & WDI 2005 WB & 79 & 0.74 & 0.26 & 0.13 & 1.02 \\
\hline $\begin{array}{l}\text { Falciparum Malaria } \\
\text { index } 1994\end{array}$ & $\begin{array}{l}\text { \% of } 1995 \text { population at risk of contracting falciparum malaria in a } \\
\text { country, } 1994\end{array}$ & $\begin{array}{c}\text { Sachs J \& Gallup J.L (2001). Dataset avalaible } \\
\text { on the website of The Earth Institute at Columbia } \\
\text { University. }\end{array}$ & 167 & 0.30 & 0.41 & 0.00 & 1.00 \\
\hline Malaria ecology & $\begin{array}{l}\text { Ecological-based spatial index of the stability of malaria } \\
\text { transmission. The index is measured on a highly disagregated } \\
\text { sub-national level (Kiszewski \& al - 2004). }\end{array}$ & $\begin{array}{c}\text { (Kiszewski \& al - 2004). Dataset avalaible on the } \\
\text { website of The Earth Institute at Columbia } \\
\text { University. }\end{array}$ & 173 & 3.65 & 6.41 & 0.00 & 31.54 \\
\hline $\begin{array}{l}\text { Log GNP per capita } \\
\text { PPP ( } \$ \text { constant } 95)\end{array}$ & Log GNP per capita PPP ( $\$$ constant), 1995 & Al Samarrai S (2006) from WDI 2000 WB & 176 & 7.55 & 1.59 & 4.69 & 10.79 \\
\hline SSA & Sub-Saharan Africa Dummy & Author \& WB & 201 & 0.23 & 0.42 & 0.00 & 1.00 \\
\hline MENA States & Middle East and North Africa Dummy & Author \& OCDE & 201 & 0.11 & 0.32 & 0.00 & 1.00 \\
\hline East Asia & East Asia Dummy & Author \& WB & 201 & 0.10 & 0.30 & 0.00 & 1.00 \\
\hline South Asia & South Asia Dummy & Author \& WB & 201 & 0.04 & 0.20 & 0.00 & 1.00 \\
\hline $\begin{array}{l}\text { Latin America and the } \\
\text { Caribbean }\end{array}$ & Latin America and the Caribbean Dummy & Author \& WB & 201 & 0.18 & 0.39 & 0.00 & 1.00 \\
\hline Subcontinents & $\begin{array}{c}1=\text { East asia, } 2=\text { Other East Asia, } 3=\text { South East Asia, } 4=\text { South } \\
\text { West Asia, } 5=\text { South Asia, } 6=0 \text { ceaania, } 7=\text { Eastern Africa, } 8= \\
\text { Middle Africa, } 9=\text { Southern Africa, } 10=\text { Western Africa, } 11= \\
\text { Caribbean, } 12=\text { Middle America, } 13=\text { Temperate South America, } \\
14=\text { Tropical South America } 15=\text { Arab States, } 16 \text { Western } \\
\text { Europe, } 17=\text { Eastern Europe, } 18=\text { North America }\end{array}$ & Author \& WB & 193 & 10.87 & 4.88 & 1.00 & 18 \\
\hline $\begin{array}{l}\text { Log Urban Pop } 1996 \\
\text { (\% total pop) }\end{array}$ & Log Urban Population (\% total pop), 1997 & Al Samarrai S (2006) from WDI 1998 WB & 191 & 3.85 & 0.55 & 1.75 & 4.6 \\
\hline $\begin{array}{l}\text { Log Under } 5 \text { Child } \\
\text { mortality } 1995\end{array}$ & $\begin{array}{l}\text { Log Mortality Rate, under five years (total per } 1000 \text { live births), } \\
\qquad 1995\end{array}$ & WDI 2005 WB & 182 & 3.72 & 1.13 & 1.54 & 5.68 \\
\hline $\begin{array}{l}\text { Log Publ Expend in } \\
\text { Prim Educ (\% GNP) } \\
1996\end{array}$ & $\begin{array}{l}\text { Log Public current expenditure in primary education as a } \\
\text { percentage of GNP, } 1996\end{array}$ & $\begin{array}{c}\text { Al Samarrai S (2006) from UNESCO EFA 2000, } \\
\text { WER } 2000\end{array}$ & 136 & -4.11 & 0.6 & -5.8 & -2.31 \\
\hline $\begin{array}{l}\text { Log Primary } \\
\text { expenditure per pupil } \\
\text { PPP } 1996\end{array}$ & $\begin{array}{l}\text { Log Public current expenditure in primary education per pupil, } \\
\text { PPP, } 1996\end{array}$ & $\begin{array}{l}\text { Al Samarrai S (2006) from UNESCO EFA 2000, } \\
\text { WER 2000 and WDI } 2000\end{array}$ & 146 & 6.21 & 1.39 & 1.09 & 8.94 \\
\hline $\begin{array}{l}\text { Log Prim School pupil- } \\
\text { teacher ratio } 90\end{array}$ & Log Primary School pupil-teacher ratio 90 & $\begin{array}{l}\text { Al Samarrai S (2006) from UNESCO 2001, WER } \\
2000\end{array}$ & 171 & 3.21 & 0.47 & 1.66 & 4.68 \\
\hline $\begin{array}{l}\text { Subtropics (\% land } \\
\text { area) }\end{array}$ & Subtropical land area (\%) & $\begin{array}{c}\text { Sachs J \& Gallup J.L (1999) CID geography } \\
\text { dataset }\end{array}$ & 150 & 0.28 & 0.32 & 0,00 & 0.98 \\
\hline Tropics (\% land area) & Tropical land area (\%) & $\begin{array}{l}\text { Sachs J \& Gallup J.L (1999) CID geography } \\
\text { dataset }\end{array}$ & 150 & 0.16 & 0.25 & 0,00 & 1,00 \\
\hline Yellow fever & \% of 1995 pop in area with yellow fever, 1996 & $\begin{array}{l}\text { Sachs J \& Gallup J.L (1999) CID geography } \\
\text { dataset }\end{array}$ & 163 & 0.12 & 0.22 & 0,00 & 0.65 \\
\hline Dengue Fever & $\%$ of 1995 pop in area with dengue, $1975-1995$ & dataset & 163 & 0.18 & 0.25 & 0,00 & 0.61 \\
\hline $\begin{array}{l}\text { Control of Corruption } \\
96\end{array}$ & $\begin{array}{l}\text { Extent to which public power is exercised for private gain, } \\
\text { including both petty and grand forms of corruption, as well as } \\
\text { "capture" of the state by elites and private interests }\end{array}$ & $\begin{array}{l}\text { Aggregate Governance Indicators from } \\
\text { Kaufmann D, Kray A \& Mastruzzi M (2006) }\end{array}$ & 151 & 0.00 & 1.00 & -2.19 & 2.50 \\
\hline $\begin{array}{l}\text { Governance } \\
\text { effectiveness } 96\end{array}$ & $\begin{array}{l}\text { The quality of public services, the quality of civil services and the } \\
\text { degree of its independence from political pressures, the quality of } \\
\text { policy formulation and implementation, and the credibility of the } \\
\text { government's commitment to such policies }\end{array}$ & $\begin{array}{l}\text { Aggregate Governance Indicators from } \\
\text { Kaufmann D, Kray A \& Mastruzzi M (2006) }\end{array}$ & 163 & 0.00 & 1.00 & -1.98 & 2.23 \\
\hline
\end{tabular}

TABLE A2: Descriptive Statistics (pairwise correlations)

\begin{tabular}{|c|c|c|c|c|c|c|c|c|c|c|c|c|}
\hline & $\begin{array}{c}\text { Primary } \\
\text { repetition rate } \\
1996 \\
\end{array}$ & $\begin{array}{c}\text { Primary } \\
\text { completion rate } \\
1996 \\
\end{array}$ & $\begin{array}{c}\text { Falciparum } \\
\text { Malaria index } \\
1994 \\
\end{array}$ & $\begin{array}{l}\text { Log GNP per } \\
\text { capita PPP (\$ } \\
\text { constant 95) }\end{array}$ & $\begin{array}{l}\text { Subtropics (\% } \\
\text { land area) }\end{array}$ & $\begin{array}{l}\text { Tropics (\% land } \\
\text { area) }\end{array}$ & $\begin{array}{c}\text { dog Urban Pop } \\
1995(\% \text { total } \\
\text { pop) } \\
\end{array}$ & $\begin{array}{c}\text { Log Under } 5 \\
\text { Child mortality } \\
1995 \\
\end{array}$ & $\begin{array}{c}\text { Log Publ } \\
\text { Expend in Prim } \\
\text { Educ } \% \text { GNP) } \\
1996 \\
\end{array}$ & $\begin{array}{l}\text { Log Primary } \\
\text { expenditure per } \\
\text { pupil PPP } 1996 \\
\end{array}$ & $\begin{array}{c}\text { Log Prim } \\
\text { School pupil- } \\
\text { teacher ratio } 90\end{array}$ & $\begin{array}{l}\text { Governement } \\
\text { Effectiveness }\end{array}$ \\
\hline $\begin{array}{l}\text { Primary repetition rate } \\
1996\end{array}$ & 1.00 & & & & & & & & & & & \\
\hline $\begin{array}{l}\text { Primary completion } \\
\text { rate } 1996\end{array}$ & -0.71 & 1.00 & & & & & & & & & & \\
\hline $\begin{array}{l}\text { Falciparum Malaria } \\
\text { index } 1994\end{array}$ & 0.54 & -0.8 & 1.00 & & & & & & & & & \\
\hline $\begin{array}{l}\text { Log GNP per capita } \\
\text { PPP ( } \$ \text { constant } 95)\end{array}$ & -0.42 & 0.65 & -0.67 & 1.00 & & & & & & & & \\
\hline $\begin{array}{l}\text { Subtropics (\% land } \\
\text { area) }\end{array}$ & 0.35 & -0.15 & 0.44 & -0.4 & 1.00 & & & & & & & \\
\hline Tropics (\% land area) & 0.38 & -0.62 & 0.54 & -0.36 & 0.11 & 1.00 & & & & & & \\
\hline $\begin{array}{l}\text { Log Urban Pop } 1995 \\
\text { (\% total pop) }\end{array}$ & -0.33 & 0.56 & -0.59 & 0.72 & -0.39 & -0.3 & 1.00 & & & & & \\
\hline $\begin{array}{l}\text { Log Under } 5 \text { Child } \\
\text { mortality } 1995\end{array}$ & 0.51 & -0.77 & 0.74 & -0.91 & 0.43 & 0.48 & -0.65 & 1.00 & & & & \\
\hline $\begin{array}{l}\text { Log Publ Expend in } \\
\text { Prim Educ (\% GNP) } \\
1996\end{array}$ & -0.15 & 0.06 & -0.09 & 0.12 & -0.12 & -0.09 & 0.05 & -0.04 & 1.00 & & & \\
\hline $\begin{array}{l}\text { Log Primary } \\
\text { expenditure per pupil } \\
\text { PPP } 1996\end{array}$ & -0.53 & 0.63 & -0.64 & 0.88 & -0.45 & -0.35 & 0.59 & -0.84 & 0.27 & 1.00 & & \\
\hline $\begin{array}{l}\text { Log Prim School pupil- } \\
\text { teacher ratio } 90\end{array}$ & 0.62 & -0.73 & 0.73 & -0.72 & 0.46 & 0.43 & -0.58 & 0.77 & -0.07 & -0.7 & 1.00 & \\
\hline $\begin{array}{l}\text { Governement } \\
\text { Effectiveness }\end{array}$ & -0.26 & 0.5 & -0.5 & 0.83 & -0.37 & -0.23 & 0.48 & -0.78 & 0.1 & 0.76 & -0.52 & 1.00 \\
\hline
\end{tabular}


TABLE A3: 2SLS results: Other controls.

\begin{tabular}{|c|c|c|c|c|c|c|c|c|}
\hline & \multicolumn{8}{|c|}{ Two Stage Least Squares: other controls } \\
\hline & \multicolumn{4}{|c|}{ Dependant variable is Primary Repetition Rate (1996) } & \multicolumn{4}{|c|}{ Dependant variable is Primary Completion Rate (1996) } \\
\hline & $\begin{array}{c}\text { (1) } \\
\text { Geografic Var }\end{array}$ & $\begin{array}{c}(2) \\
\text { Health Var }\end{array}$ & $\begin{array}{c}\text { (3) } \\
\text { Resources Var }\end{array}$ & $\begin{array}{c}(4) \\
\text { Governance Var }\end{array}$ & $\begin{array}{c}\text { (5) } \\
\text { Geografic Var }\end{array}$ & $\begin{array}{c}6) \\
\text { Health Var }\end{array}$ & $\begin{array}{c}\quad(7) \\
\text { Resources Var }\end{array}$ & $\begin{array}{c}(8) \\
\text { Governance Var }\end{array}$ \\
\hline $\begin{array}{l}\text { Falciparum Malaria } \\
\text { index } 1994\end{array}$ & $\begin{array}{c}0.136 \\
(0.090)\end{array}$ & $\begin{array}{l}0.129^{* *} \\
(0.062)\end{array}$ & $\begin{array}{c}0.093^{* * *} \\
(0.037)\end{array}$ & $\begin{array}{l}0.114^{* * *} \\
(0.036)\end{array}$ & $\begin{array}{c}-0.713^{* * *} \\
(0.232)\end{array}$ & $\begin{array}{c}-0.539^{* * *} \\
(0.199)\end{array}$ & $\begin{array}{c}-0.494^{* * *} \\
(0.104)\end{array}$ & $\begin{array}{c}-0.495^{* * *} \\
(0.081)\end{array}$ \\
\hline $\begin{array}{l}\text { Log GNP per capita } \\
\text { PPP ( } \$ \text { constant } 95)\end{array}$ & $\begin{array}{c}0.001 \\
(0.006)\end{array}$ & $\begin{array}{l}0.024^{* *} \\
(0.010)\end{array}$ & $\begin{array}{l}0.019^{\star} \\
(0.010)\end{array}$ & $\begin{array}{l}0.014 \\
(0.013)\end{array}$ & $\begin{array}{c}0.015 \\
(0.023)\end{array}$ & $\begin{array}{c}0.011 \\
(0.036)\end{array}$ & $\begin{array}{c}0.020 \\
(0.027)\end{array}$ & $\begin{array}{c}0.013 \\
(0.039)\end{array}$ \\
\hline SSA & $\begin{array}{l}0.016 \\
(0.066)\end{array}$ & - & - & - & $\begin{array}{l}0.156 \\
(0.178)\end{array}$ & - & - & - \\
\hline $\begin{array}{l}\text { Middle East and North } \\
\text { Africa }\end{array}$ & $\begin{array}{c}0.031 \\
(0.019)\end{array}$ & - & - & - & $\begin{array}{l}-0.059 \\
(0.073)\end{array}$ & - & - & - \\
\hline East Asia & $\begin{array}{c}0.005 \\
(0.028)\end{array}$ & - & - & - & $\begin{array}{c}0.112 \\
(0.071)\end{array}$ & - & - & - \\
\hline South Asia & $\begin{array}{c}0.020 \\
(0.032)\end{array}$ & - & - & - & - & - & - & - \\
\hline $\begin{array}{l}\text { Latin America and the } \\
\text { Caribbean }\end{array}$ & $\begin{array}{l}0.061^{* * *} \\
(0.013)\end{array}$ & - & - & - & $\begin{array}{l}-0.025 \\
(0.048)\end{array}$ & - & - & - \\
\hline $\begin{array}{l}\text { Log Under } 5 \text { Child } \\
\text { mortality } 1995\end{array}$ & - & $\begin{array}{l}0.041^{* *} \\
(0.020)\end{array}$ & - & - & - & $\begin{array}{l}-0.013 \\
(0.074)\end{array}$ & - & - \\
\hline Yellow fever 96 & & $\begin{array}{l}-0.078 \\
(0.074)\end{array}$ & - & - & - & $\begin{array}{c}0.056 \\
(0.202)\end{array}$ & - & \\
\hline Dengue Fever 75-95 & & $\begin{array}{l}0.046 \\
(0.034)\end{array}$ & - & - & - & $\begin{array}{l}-0.072 \\
(0.096)\end{array}$ & - & \\
\hline $\begin{array}{l}\text { Log Publ Expend in } \\
\text { Prim Educ (\% GNP) } \\
1996\end{array}$ & - & - & $\begin{array}{l}-0.006 \\
(0.013)\end{array}$ & - & - & - & $\begin{array}{l}-0.005 \\
(0.026)\end{array}$ & - \\
\hline $\begin{array}{l}\text { Log Primary } \\
\text { expenditure per pupil } \\
\text { PPP } 1996\end{array}$ & - & - & $\begin{array}{l}-0.012 \\
(0.012)\end{array}$ & - & - & - & $\begin{array}{c}0.008 \\
(0.022)\end{array}$ & - \\
\hline $\begin{array}{l}\text { Log Prim School pupil- } \\
\text { teacher ratio } 96\end{array}$ & - & - & $\begin{array}{l}0.100^{* * *} \\
(0.030)\end{array}$ & - & - & - & $\begin{array}{l}-0.033 \\
(0.088)\end{array}$ & - \\
\hline Corruption 96 & - & - & - & $\begin{array}{c}0.027 \\
(0.018)\end{array}$ & - & & & $\begin{array}{l}-0.041 \\
(0.048)\end{array}$ \\
\hline $\begin{array}{l}\text { Government } \\
\text { Effectiveness } 96\end{array}$ & - & - & - & $\begin{array}{c}-0.055^{\star \star} \\
(0.021)\end{array}$ & - & - & - & $\begin{array}{c}0.049 \\
(0.061)\end{array}$ \\
\hline Intercept & $\begin{array}{c}0.000 \\
(0.059)\end{array}$ & $\begin{array}{c}-0.301^{* *} \\
(0.136)\end{array}$ & $\begin{array}{l}-0.363^{* *} \\
(0.152)\end{array}$ & $\begin{array}{l}-0.073 \\
(0.112)\end{array}$ & $\begin{array}{c}0.794^{* * *} \\
(0.193)\end{array}$ & $\begin{array}{c}0.865 \\
(0.469)\end{array}$ & $\begin{array}{c}0.770 \\
(0.417)\end{array}$ & $\begin{array}{l}0.793^{* *} \\
(0.316)\end{array}$ \\
\hline Number ofobservations & 117 & 114 & 85 & 108 & 73 & 71 & 56 & 68 \\
\hline$R$ squared & 0.36 & 0.36 & 0.55 & 0.36 & 0.60 & 0.64 & 0.77 & 0.61 \\
\hline
\end{tabular}

1. Robust standard errors, adjusted for heteroscedasticity are used in all cases.

2. Standard errors in parenthesis

3. ${ }^{* * *}$ denotes statistical significance at the $1 \%$ level, ${ }^{* *}$ at the $5 \%$ level, ${ }^{*}$ at the $10 \%$ level.

5. Instrument used is malaria ecology which is an ecological-based spatial index of the stability of malaria transmission. The index is measured on a highly disagregated sub-national level (Kiszewski \& al - 2004).

6. The p.value of the coefficient estimate on the falciparum malaria index 1994 in regression (1) is 0,13 .

7. In regression (5), South Asia was dropped because there is no South-Asian country in the sample. 
TABLE A4: 2SLS with observations clustered within subcontinents.

\begin{tabular}{|c|c|c|c|c|c|c|}
\hline & \multicolumn{6}{|c|}{ Two Stage Least Squares regressions (2SLS) with clusters } \\
\hline & \multicolumn{3}{|c|}{$\begin{array}{c}\text { Dependant variable is Primary Repetition } \\
\text { Rate (1996) }\end{array}$} & \multicolumn{3}{|c|}{$\begin{array}{c}\text { Dependant variable is Primary Completion } \\
\text { Rate (1996) }\end{array}$} \\
\hline & $(1)$ & $(2)$ & (3) & $(4)$ & (5) & (6) \\
\hline $\begin{array}{l}\text { Falciparum Malaria } \\
\text { index } 1994\end{array}$ & $\begin{array}{l}0.180^{* *} \\
(0.027)\end{array}$ & $\begin{array}{c}0.185^{* * *} \\
(0.070)\end{array}$ & $\begin{array}{c}0.111 \\
(0.070)\end{array}$ & $\begin{array}{c}-0.543^{* * *} \\
(0.212)\end{array}$ & $\begin{array}{c}-0.554^{* *} \\
(0.211)\end{array}$ & $\begin{array}{l}-0.480^{*} \\
(0.274)\end{array}$ \\
\hline $\begin{array}{l}\text { Log GNP per capita } \\
\text { PPP ( } \$ \text { constant } 95)\end{array}$ & $\begin{array}{c}0.019 \\
(0.017)\end{array}$ & $\begin{array}{l}0.030 \\
(0.021)\end{array}$ & $\begin{array}{l}0.034^{* *} \\
(0.017)\end{array}$ & $\begin{array}{c}0.029 \\
(0.076)\end{array}$ & $\begin{array}{c}0.002 \\
(0.059)\end{array}$ & $\begin{array}{l}-0.009 \\
(0.071)\end{array}$ \\
\hline $\begin{array}{l}\text { Subtropics (\% land } \\
\text { area) }\end{array}$ & $\begin{array}{c}0.021 \\
(0.042)\end{array}$ & $\begin{array}{c}0.009 \\
(0.040)\end{array}$ & $\begin{array}{l}0.006 \\
(0.027)\end{array}$ & $\begin{array}{l}0.013 \\
(0.124)\end{array}$ & $\begin{array}{l}0.047 \\
(0.117)\end{array}$ & $\begin{array}{l}0.065 \\
(0.118)\end{array}$ \\
\hline Tropics (\% land area) & $\begin{array}{l}-0.019 \\
(0.044)\end{array}$ & $\begin{array}{l}-0.025 \\
(0.043)\end{array}$ & $\begin{array}{l}-0.011 \\
(0.042)\end{array}$ & $\begin{array}{l}0.069 \\
(0.111)\end{array}$ & $\begin{array}{c}0.089 \\
(0.119)\end{array}$ & $\begin{array}{c}0.074 \\
(0.116)\end{array}$ \\
\hline $\begin{array}{l}\text { Log Urban Pop (\% total } \\
\text { pop) }\end{array}$ & $\begin{array}{c}0.042 \\
(0.031)\end{array}$ & $\begin{array}{c}0.039 \\
(0.036)\end{array}$ & $\begin{array}{l}0.026 \\
(0.034)\end{array}$ & $\begin{array}{c}0.042 \\
(0.056)\end{array}$ & $\begin{array}{c}0.053 \\
(0.060)\end{array}$ & $\begin{array}{l}0.068 \\
(0.063)\end{array}$ \\
\hline $\begin{array}{l}\text { Log Under } 5 \text { Child } \\
\text { mortality } 1995\end{array}$ & $\begin{array}{c}0.029 \\
(0.026)\end{array}$ & $\begin{array}{c}0.026 \\
(0.027)\end{array}$ & $\begin{array}{c}0.025 \\
(0.023)\end{array}$ & $\begin{array}{c}0.000 \\
(0.123)\end{array}$ & $\begin{array}{c}0.000 \\
(0.127)\end{array}$ & $\begin{array}{l}-0.012 \\
(0.136)\end{array}$ \\
\hline $\begin{array}{l}\text { Log Publ Expend in } \\
\text { Prim Educ (\% GNP) } \\
1996\end{array}$ & $\begin{array}{l}-0.017 \\
(0.016)\end{array}$ & $\begin{array}{l}-0.012 \\
(0.019)\end{array}$ & $\begin{array}{l}-0.014 \\
(0.020)\end{array}$ & $\begin{array}{c}0.001 \\
(0.029)\end{array}$ & $\begin{array}{l}-0.002 \\
(0.037)\end{array}$ & $\begin{array}{c}0.002 \\
(0.040)\end{array}$ \\
\hline $\begin{array}{l}\text { Log Primary } \\
\text { expenditure per pupil } \\
\text { PPP } 1996\end{array}$ & - & $\begin{array}{l}-0.010 \\
(0.015)\end{array}$ & $\begin{array}{l}-0.007 \\
(0.013)\end{array}$ & - & $\begin{array}{c}0.023 \\
(0.024)\end{array}$ & $\begin{array}{c}0.022 \\
(0.023)\end{array}$ \\
\hline $\begin{array}{l}\text { Log Prim School pupil- } \\
\text { teacher ratio } 96\end{array}$ & - & - & $\begin{array}{l}0.083^{* *} \\
(0.040)\end{array}$ & - & - & $\begin{array}{l}-0.055 \\
(0.091)\end{array}$ \\
\hline $\begin{array}{l}\text { Government } \\
\text { Effectiveness }\end{array}$ & $\begin{array}{l}-0.014 \\
(0.017)\end{array}$ & $\begin{array}{l}-0.017 \\
(0.016)\end{array}$ & $\begin{array}{l}-0.017 \\
(0.014)\end{array}$ & $\begin{array}{c}0.003 \\
(0.048)\end{array}$ & $\begin{array}{c}0.005 \\
(0.041)\end{array}$ & $\begin{array}{l}0.002 \\
(0.040)\end{array}$ \\
\hline Intercept & $\begin{array}{l}-0.466^{* *} \\
(0.209)\end{array}$ & $\begin{array}{l}-0.432^{*} \\
(0.250)\end{array}$ & $\begin{array}{l}-0.692 \\
(0.270)\end{array}$ & $\begin{array}{l}0.497 \\
(0.912)\end{array}$ & $\begin{array}{c}0.483 \\
(1.088)\end{array}$ & $\begin{array}{c}0.737 \\
(1.329)\end{array}$ \\
\hline Number ofobservations & 84 & 82 & 80 & 55 & 54 & 54 \\
\hline$R$ squared & 0.46 & 0.48 & 0.58 & 0.75 & 0.77 & 0.79 \\
\hline
\end{tabular}

Notes:

1. Robust standard errors, adjusted for heteroscedasticity are used in all cases.

2. Standard errors in parenthesis

3. ${ }^{* *}$ denotes statistical significance at the $1 \%$ level, ${ }^{* *}$ at the $5 \%$ level, ${ }^{*}$ at the $10 \%$ level.

5. Instrument used in two stage least squares is malaria ecology which is an ecological-based spatial index of the stability of malaria transmission. The index is measured on a highly disagregated sub-national level (Kiszewski \& al - 2004).

6. The p.value of the coefficient estimate on the falciparum malaria index 1994 in regression (3) is $0,13$. 
TABLE A5: 2SLS Regressions controlling for outliers.

\begin{tabular}{|c|c|c|c|c|c|c|}
\hline & \multicolumn{6}{|c|}{ Two Stage Least Squares regressions (2SLS) without influencial observations } \\
\hline & \multicolumn{3}{|c|}{$\begin{array}{c}\text { Dependant variable is Primary Repetition } \\
\text { Rate (1996) }\end{array}$} & \multicolumn{3}{|c|}{$\begin{array}{c}\text { Dependant variable is Primary Completion } \\
\text { Rate (1996) }\end{array}$} \\
\hline & $(1)$ & $(2)$ & (3) & $(4)$ & (5) & (6) \\
\hline $\begin{array}{l}\text { Falciparum Malaria index } \\
1994\end{array}$ & $\begin{array}{c}0.132^{* * *} \\
(0.051)\end{array}$ & $\begin{array}{l}0.132^{* *} \\
(0.060)\end{array}$ & $\begin{array}{c}0.094 \\
(0.083)\end{array}$ & $\begin{array}{c}-0.633^{* * *} \\
(0.213)\end{array}$ & $\begin{array}{c}-0.631^{* * *} \\
(0.202)\end{array}$ & $\begin{array}{l}-0.585^{* *} \\
(0.254)\end{array}$ \\
\hline $\begin{array}{l}\text { Log GNP per capita PPP } \\
\text { ( } \$ \text { constant } 95)\end{array}$ & $\begin{array}{l}0.028^{* *} \\
(0.011)\end{array}$ & $\begin{array}{l}0.043^{* *} \\
(0.017)\end{array}$ & $\begin{array}{c}0.049^{* * *} \\
(0.017)\end{array}$ & $\begin{array}{c}0.025 \\
(0.043)\end{array}$ & $\begin{array}{l}0.003 \\
(0.049)\end{array}$ & $\begin{array}{l}-0.005 \\
(0.056)\end{array}$ \\
\hline Subtropics (\% land area) & $\begin{array}{l}0.046^{* *} \\
(0.022)\end{array}$ & $\begin{array}{c}0.034 \\
(0.027)\end{array}$ & $\begin{array}{c}0.014 \\
(0.027)\end{array}$ & $\begin{array}{l}-0.024 \\
(0.081)\end{array}$ & $\begin{array}{c}0.005 \\
(0.080)\end{array}$ & $\begin{array}{l}-0.003 \\
(0.103)\end{array}$ \\
\hline Tropics (\% land area) & $\begin{array}{c}0.002 \\
(0.041)\end{array}$ & $\begin{array}{l}-0.005 \\
(0.048)\end{array}$ & $\begin{array}{l}0.017 \\
(0.062)\end{array}$ & $\begin{array}{c}0.079 \\
(0.104)\end{array}$ & $\begin{array}{c}0.101 \\
(0.105)\end{array}$ & $\begin{array}{l}0.102 \\
(0.111)\end{array}$ \\
\hline $\begin{array}{l}\text { Log Urban Pop ( } \% \text { total } \\
\text { pop) }\end{array}$ & $\begin{array}{c}0.014 \\
(0.020)\end{array}$ & $\begin{array}{l}-0.017 \\
(0.025)\end{array}$ & $\begin{array}{l}-0.003 \\
(0.029)\end{array}$ & $\begin{array}{c}0.071 \\
(0.063)\end{array}$ & $\begin{array}{c}0.071 \\
(0.079)\end{array}$ & $\begin{array}{c}0.089 \\
(0.079)\end{array}$ \\
\hline $\begin{array}{l}\text { Log Under } 5 \text { Child } \\
\text { mortality } 1995\end{array}$ & $\begin{array}{l}0.040^{* *} \\
(0.016)\end{array}$ & $\begin{array}{l}0.036^{* *} \\
(0.017)\end{array}$ & $\begin{array}{l}0.037^{* *} \\
(0.017)\end{array}$ & $\begin{array}{c}0.039 \\
(0.087)\end{array}$ & $\begin{array}{c}0.023 \\
(0.069)\end{array}$ & $\begin{array}{c}0.020 \\
(0.074)\end{array}$ \\
\hline $\begin{array}{l}\text { Log Publ Expend in Prim } \\
\text { Educ (\% GNP) } 1996\end{array}$ & $\begin{array}{l}-0.008 \\
(0.008)\end{array}$ & $\begin{array}{c}0.000 \\
(0.011)\end{array}$ & $\begin{array}{l}-0.005 \\
(0.013)\end{array}$ & $\begin{array}{c}0.018 \\
(0.029)\end{array}$ & $\begin{array}{c}0.021 \\
(0.022)\end{array}$ & $\begin{array}{c}0.029 \\
(0.021)\end{array}$ \\
\hline $\begin{array}{l}\text { Log Primary expenditure } \\
\text { per pupil PPP } 1996\end{array}$ & - & $\begin{array}{l}-0.019 \\
(0.017)\end{array}$ & $\begin{array}{l}-0.011 \\
(0.021)\end{array}$ & - & $\begin{array}{c}0.011 \\
(0.020)\end{array}$ & $\begin{array}{l}0.015 \\
(0.016)\end{array}$ \\
\hline $\begin{array}{l}\text { Log Prim School pupil- } \\
\text { teacher ratio } 96\end{array}$ & - & - & $\begin{array}{l}0.042^{\star} \\
(0.024)\end{array}$ & - & - & $\begin{array}{l}-0.023 \\
(0.095)\end{array}$ \\
\hline $\begin{array}{l}\text { Government } \\
\text { Effectiveness }\end{array}$ & $\begin{array}{l}-0.011 \\
(0.013)\end{array}$ & $\begin{array}{l}-0.011 \\
(0.014)\end{array}$ & $\begin{array}{l}-0.021 \\
(0.014)\end{array}$ & $\begin{array}{c}0.041 \\
(0.047)\end{array}$ & $\begin{array}{l}0.035 \\
(0.039)\end{array}$ & $\begin{array}{c}0.023 \\
(0.034)\end{array}$ \\
\hline Intercept & $\begin{array}{l}-0.422 \\
(0.137)\end{array}$ & $\begin{array}{c}-0.287^{\star *} \\
(0.152)\end{array}$ & $\begin{array}{c}-0.540^{\star * \star} \\
(0.205)\end{array}$ & $\begin{array}{c}0.393 \\
(0.552)\end{array}$ & $\begin{array}{c}0.532 \\
(0.446)\end{array}$ & $\begin{array}{c}0.536 \\
(0.619)\end{array}$ \\
\hline Number ofobservations & 73 & 71 & 69 & 47 & 46 & 45 \\
\hline$R$ squared & 0.63 & 0.65 & 0.64 & 0.87 & 0.91 & 0.91 \\
\hline
\end{tabular}

\section{Notes:}

1. Robust standard errors, adjusted for heteroscedasticity are used in all cases.

2. Standard errors in parenthesis

3. ${ }^{* *}$ denotes statistical significance at the $1 \%$ level, ${ }^{* *}$ at the $5 \%$ level, ${ }^{*}$ at the $10 \%$ level.

5. Instrument used in two stage least squares is malaria ecology which is an ecological-based spatial index of the stability of malaria transmission. The index is measured on a highly disagregated sub-national level (Kiszewski \& al - 2004).

6. 11 countries were identified as influencial observations for regressions with primary repetition rates. For instance, the 11 observations dropped in regression (1) are: Cambodia, Chad, Congo, Gabon, Kenya, Lesotho, Madagascar, Nicaragua, Papua New Guinea, Uganda, Zambia.

7. From 8 to 9 countries were identified as influencial observations for regressions with primary completion rates. For instance the 8 observations dropped in regression (4) are: China, Gabon, Indonesia, Kyrgyz Republic, Morocco, Nicaragua, Saudi Arabia, Switzerland. 